\title{
Experimental model for collagen estimation in cell culture ${ }^{1}$
}

\author{
Sidney Mamoru Keira ${ }^{2}$ \\ Lydia Masako Ferreira ${ }^{3}$ \\ Alfredo Gragnani ${ }^{4}$ \\ Ivone da Silva Duarte ${ }^{5}$ \\ José Barbosa ${ }^{6}$
}

Keira SM, Ferreira LM, Gragnani A, Duarte IS, Barbosa J. Experimental model for collagen estimation in cell culture. Acta Cir Bras [serial online] 2004 Vol 19 Special Edition. Available on URL: http://www.scielo.br/acb.

ABSTRACT - In the study of Plastic Surgery, cell culture may be used at experimental level in researches concerning biosynthesis functions of skin cells such as fibroblasts, keratinocytes, adipocytes, chondrocytes and osteocytes. The present study reports an experimental model for estimation of collagen in cell cultures using chromogenic precipitation reaction with an especific dye (Sirius Red).

KEY WORDS - Cells, cultured. Collagen. Dye.

Introduction

The manipulation of cutaneous compartment in Plastic Surgery is of primary importance since the healing quality is one of the criteria used for evaluating the results of esthetic and reconstructive surgical procedures.

The behavior of cutaneous cells can be investigated with the use of culture of skin cells as fibroblasts and keratinocytes.

Among several methods in vitro, fibroblast culture is an important tool for evaluation of the connective tissue, considering cell proliferation kinetics and synthesis of several components of the extra-cellular matrix.

Some physical-chemical methods are used to measure the amount of substances produced by fibroblasts in culture - chromogenic reactions (specific dyes), molecular weight comparisons (poliacrilamide or agarose gel electrophoresis and chromatography), immunological reactions (specific antigen-antibody reactions) and radioactive procedures (radioactive isotopes markers).

\section{Proposition}

The proposition of the present study is to describe an application of a collagen mensuration method by means of a chromogenic reaction between the molecule of this protein and an already described ${ }^{1,2,3}$ specific dye ${ }^{4,5}$ Sirius Red F3B in fibroblast culture.

\footnotetext{
${ }^{1}$ Study developed in the Laboratory of Cell Culture, Plastic Surgery Division, Federal University of Sao Paulo - Sao Paulo Medical School.

${ }^{2}$ MD, PhD, Plastic Surgery Division, Federal University of Sao Paulo - Sao Paulo Medical School. ${ }^{3} \mathrm{MD}$, PhD, Titular and Head of the Plastic Surgery Division, Federal University of Sao Paulo - Sao Paulo Medical School.

${ }^{4} \mathrm{MD}$, PhD, Plastic Surgery Division, Federal University of Sao Paulo - Sao Paulo Medical School 5 MD, PhD, Plastic Surgery Division, Federal University of Sao Paulo - Sao Paulo Medical School. Dentist, Head of the General and Bucal Pathology Division, University Paulista-Objetivo, Sao Paulo.
} 


\section{Method description}

The description of this experimental model will be described as follows - (1) harvesting of collagen from the cellular layer and the culture medium of a fibroblast culture; and (2) reaction of chromogenic precipitation between collagen and the dye Sirius Red F3B.

Collagen extraction from cellular layer and culture medium.

Extraction of total protein and collagen from the cellular layer (FIGURE 1).

SCRAPPED CELLULAR LAYER

$\mathrm{V}=5,0 \mathrm{~mL}$

$\downarrow$

SONICATION

$\lambda=10 \mu \mathrm{M}, \Delta \mathrm{t}=15 \mathrm{~s}, 3 \times(15 / 30 \mathrm{~s}), \mathrm{T}=4^{\circ} \mathrm{C}$

$\downarrow \quad[+]$

$\left(\mathrm{NH}_{4}\right)_{2} \mathrm{SO}_{4} \mathbf{2 5 \%}$ saturation in aqueous solution $\mathrm{V}=15,0 \mathrm{ml}, \Delta \mathrm{t}=24 \mathrm{~h}, \mathrm{~T}=4^{\circ} \mathrm{C}$, constant agitation

$\downarrow$

CENTRIFUGATION

$40.000 \times \mathrm{g}, \Delta \mathrm{t}=30 \mathrm{~min}, \mathrm{~T}=4^{\circ} \mathrm{C}$

K

$y$

SUPERNATANT

PELLET

$\downarrow$

HAc 0,5 M

$\mathrm{V}=2,0 \mathrm{ml}$

$\downarrow$

CELLULAR LAYER COLLAGEN

ALIQUOT

FIGURE 1 - Process of total protein and collagen extraction from the cellular layer. [+] aliquots of total protein from the cellular layer.

Total protein and collagen from the cellular layer was obtained with the addition of a protein extraction solution after rinsing the culture flasks with PBS. This solution consisted of a protease inhibitor cocktail in PBS (5,0 ml) - EDTA $10 \mathrm{mM}$ (Aldrich Chemical Co., Milwaukee, USA), N-etilmaleimide $10 \mathrm{mM}$ (Sigma-Aldrich Chemical Co., Saint Louis, USA), and PMSF 
1mM (Sigma-Aldrich Chemical Co., Saint Louis, USA). Then cellular layer was harvested by scraping it at $4^{\circ} \mathrm{C}$.

Total protein from the cellular layer was obtained by sonication of the cellular layer extract ( 3 x $15 \mathrm{~s}$, with $30 \mathrm{~s}$ intervals, $20 \mathrm{~Hz}, 4^{\circ} \mathrm{C}$ ).

The sonicated was submitted to a collagen precipitation reaction with $25 \%$ saturated ammonium sulfate, for 24 hours at $4^{\circ} \mathrm{C}$, under constant agitation ${ }^{6}$. Then collagen was isolated by centrifugation ( $40.000 \times \mathrm{g}, 30$ minutes, $\left.4^{\circ} \mathrm{C}\right)$.

The supernatant was disposed and the pellet was solubilized in 2,0 $\mathrm{ml}$ of acetic acid 0,5 M (Merck, Darmstadt, Germany), consisting the aliquots of collagen from the cellular layer.

Extraction of collagen from the culture medium (FIGURE 2).

Collagen from the culture medium was precipitated, as in the cellular layer, with $25 \%$ saturated ammonium sulfate, for 24 hours at $4^{\circ} \mathrm{C}$, under constant agitation ${ }^{6}$. Then this solution was centrifuged $\left(40.000 \times \mathrm{g}, 30 \mathrm{~min}, 4^{\circ} \mathrm{C}\right)$.

The pellet was dissolved in 2,0 $\mathrm{ml}$ acetic acid $0,5 \mathrm{M}$, which consisted of the collagen aliquot from the culture medium.

\section{$\Sigma$ of ALIQUOTS OF CULTURE MEDIUM}

$$
\mathrm{V}=28,0 \mathrm{ml}
$$

$\left(\mathrm{NH}_{4}\right)_{2} \mathrm{SO}_{4} 25 \%$ saturation in aqueous solution

$\mathrm{V}=84 \mathrm{ml}, \Delta \mathrm{t}=24 \mathrm{~h}, \mathrm{~T}=4^{\circ} \mathrm{C}$, constant agitation

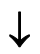

\section{CENTRIFUGATION}

$40.000 \times \mathrm{g}, \Delta \mathrm{t}=30 \mathrm{~min}, \mathrm{~T}=4^{\circ} \mathrm{C}$

$\boldsymbol{k}$

SUPERNATANT $y$

PELLET

$\downarrow$

HAc 0,5 M

$\mathrm{V}=2,0 \mathrm{ml}$

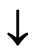

CULTURE MEDIUM COLLAGEN

ALIQUOT

FIGURE 2 - Process of collagen extration from the culture medium.

Collagen chromogenic precipitation with Sirius Red (TABLE 1, FIGURES 3, 4, 5).

Small amounts $(100 \mu \mathrm{l})$ of collagen aliquots from the cellular layer and the culture medium were put in 1,8 ml conic tubes and the collagen was precipitated with $1 \mathrm{ml}$ of a solution of dye Sirius Red (Sigma-Aldrich Chemical Co., Saint Louis, EUA) $50 \mu \mathrm{M}(69 \mu \mathrm{g} / \mathrm{ml})$ in acetic acid $0,5 \mathrm{M}$. After shaking, the tubes were maintained in rest for 30 minutes at environment temperature and then centrifuged for 30 minutes at $30.000 \mathrm{xg}$. 
The supernatant was disposed and the pellet was eluted in $1 \mathrm{~mL}$ potassium hydroxid $\mathrm{KOH}$ 0,1 N (Merck, Darmstadt, Germany) for 15 minutes, in environment temperature (FIGURE 3).

Then, absorbance of the eluted was determined in spectrophotometer of $540 \mathrm{~nm}$ wavelength. Optic densities obtained were interpolated in a curve of absorbance, using collagen type I from rat tail soluble in acetic acid (Merck, Darmstadt, Germany) as standard (FIGURE 3, TABLE 1).

TABLE 1 - Absorbance (540 nm) of the eluted from the collagen precipitation reaction with the dye Sirius Red (collagen type I from rat tail soluble in acetic acid - standard curve).

\begin{tabular}{cc}
\hline COLLAGEN $(\boldsymbol{\mu g})$ & PELLET ELUTION ABSORBANCE \\
\hline 0 & 0 \\
5 & 0,067 \\
10 & 0,090 \\
25 & 0,209 \\
50 & 0,382 \\
100 & 0,656 \\
\hline
\end{tabular}

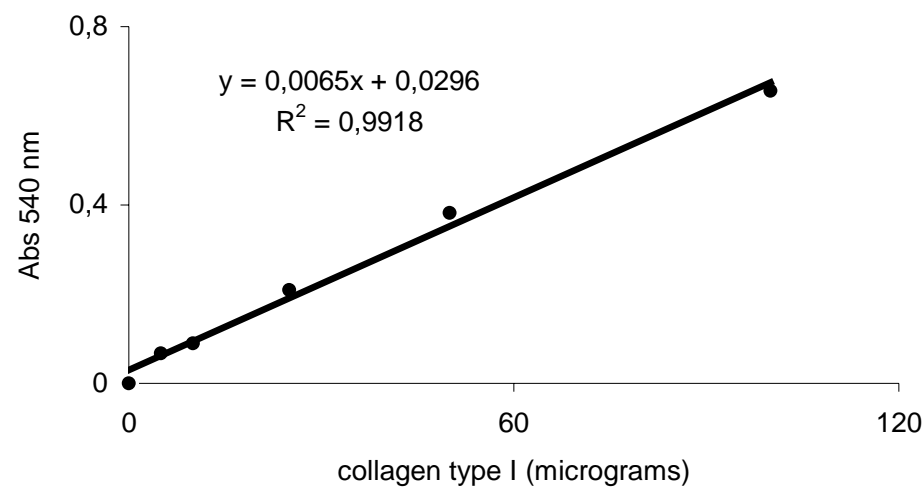

FIGURE 3 - Standard curve of absorbance $(540 \mathrm{~nm})$ of the eluted from the collagen precipitation reaction with the dye Sirius Red (collagen type I from rat tail soluble in acetic acid.

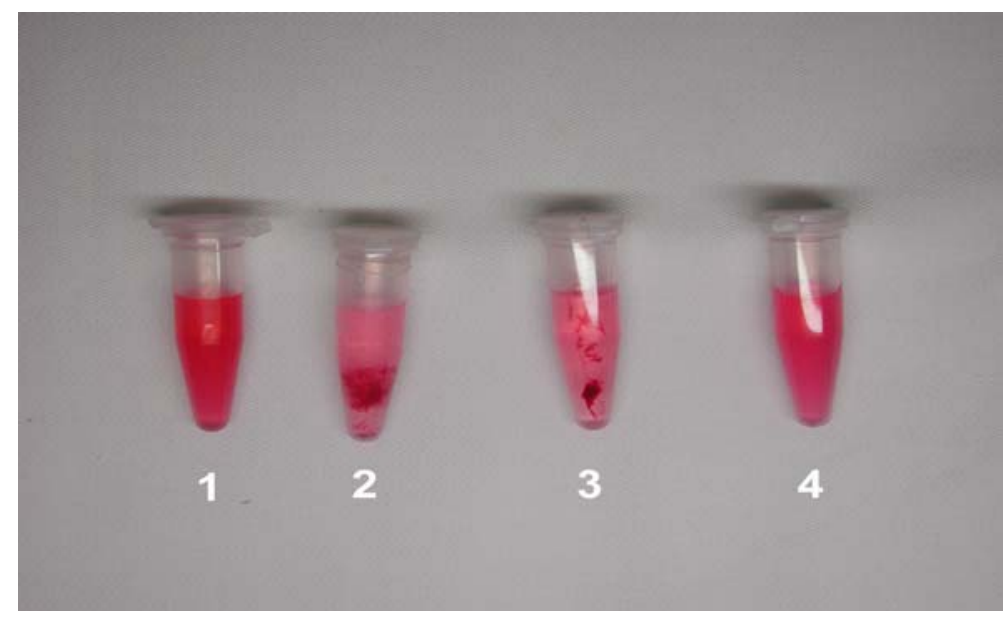

FIGURE 4 - Conic tubes $(1,8 \mathrm{ml})$ with the steps of collagen mensuration with chromogenic precipitation reaction with dye Sirius Red. (1) addition of dye, (2) 30 minutes after addition of dye, with filaments (complex collagen-dye) in red, (3) post-centrifugation, with complex collagen-dye precipitated in the bottom of the tube, (4) post-elution with $\mathrm{KOH} \mathrm{0,1} \mathrm{N} \mathrm{solution.}$ 


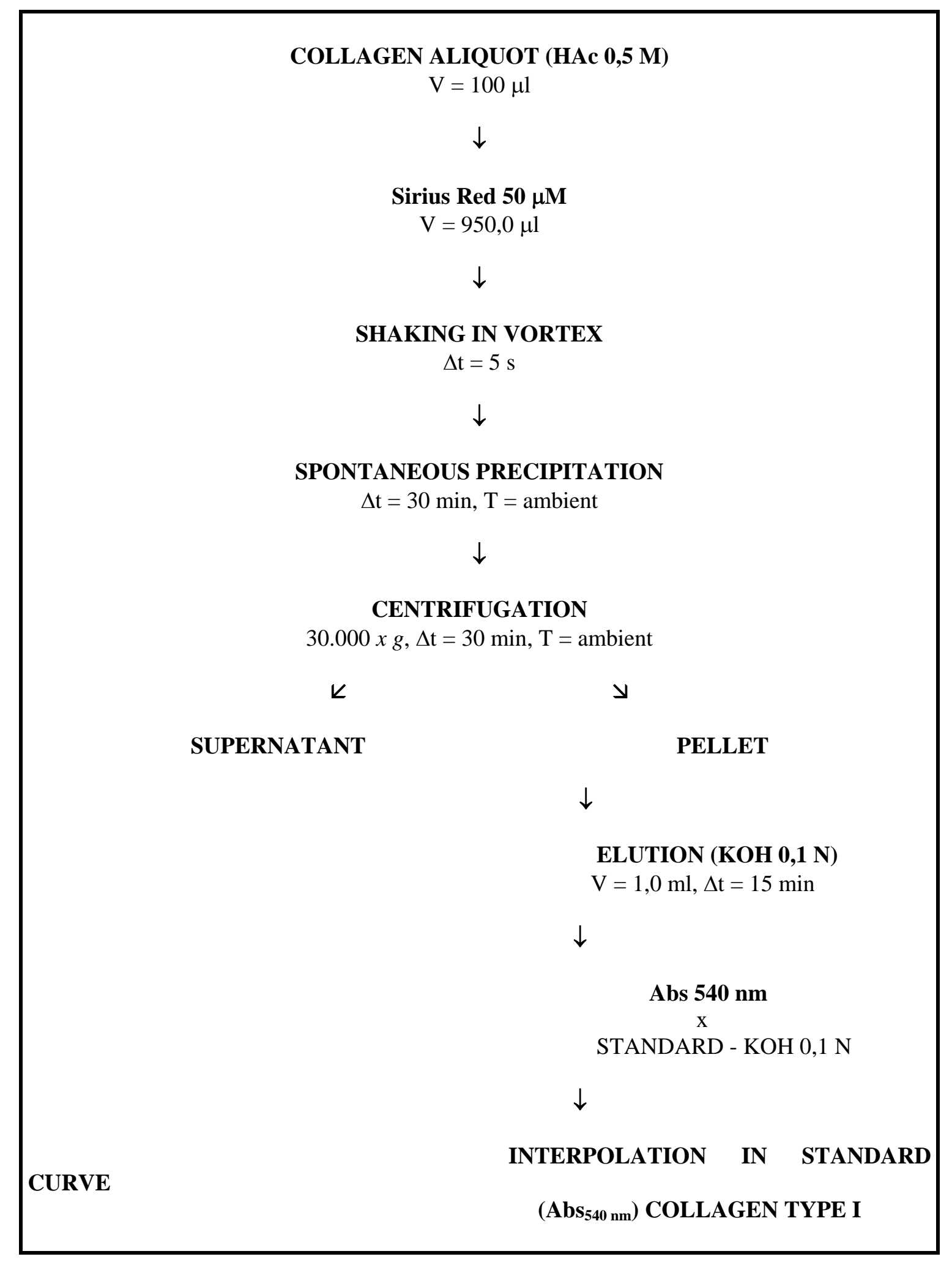

FIGURE 5 - Process of collagen chromogenic precipitation reaction with the dye Sirius Red F3B in aliquots from fibroblast culture. 


\section{Perspectives}

The experimental model for mensuration of collagen content by chromogenic precipitation reaction with the specific dye Sirius Red F3B showed satisfactory in proteic aliquots obtained from fibroblast culture. This procedure showed as an simple and cheap option to estimate the concentration of collagen in the cellular layer and the culture medium of fibroblast culture.

The possibility of cross-reaction between the dye Sirius Red F3B and the molecule of complement C1q (rich in hydroxiproline) was described ${ }^{3}$. Anyway this fact was not considered relevant in the present model since the possibility of the existence of this molecule in the experimental aliquots from fibroblast culture is remote.

\section{References}

1. Junqueira LCU, Bignolas G, Brentani RR - A simple and sensitive method for the quantitative estimation of collagen. Anal Biochem. 1979b;94:96-9.

2. Marotta M, Martino G - Sensitive spectrophotometric method for the quantitative estimation of collagen. Anal Biochem. 1985;150:86-90.

3. Walsh BJ, Thornton SC, Penny R, Breit SN - Microplate reader-based quantitation of collagens. Anal Biochem. 1992;203:187-90.

4. Sweat F, Puchtler H, Rosenthal SI - Sirius Red F3BA as stain for connective tissue. Arch Pathol. 1964;78:69-72.

5. Junqueira LCU, Bignolas G, Brentani RR - Picrosirius staining plus polarization microscopy, a specific method for collagen detection in tissue sections. Histochem. J 1979a;11:447-55.

6. Trelstad RL, Catanese VM, Rubin DF - Collagen fractionation: separation of native types I, II and III by differential precipitation. Anal Biochem. 1976;71:114-8.

Keira SM, Ferreira LM, Gragnani A, Duarte IS, Barbosa J. Modelo experimental para avaliação do colágeno em cultura de células. Acta Cir Bras [serial online] 2004 Vol 19 Edição Especial. Disponível em URL: http://www.scielo.br/acb.

RESUMO - Dentro do estudo da Cirurgia Plástica, a cultura de células pode ser utilizada em experimentos relativos às funções de biossíntese de células relacionadas com a pele tais como fibroblastos, queratinócitos, adipócitos, condrócitos e osteócitos. O presente estudo relata modelo experimental para a mensuração estimada do colágeno em cultura de células utilizandose uma reação de precipitação cromogênica com um corante específico (Sirius Red).

DESCRITORES - Cultura de células. Colágeno. Corante.

Conflito de interesse: nenhum

Fonte de financiamento: nenhum

Correspondence:

Sidney Mamoru Keira

UNIFESP-EPM, Plastic Surgery Division, Surgery Division

Rua Napoleão de Barros, 715, $4^{\circ}$ andar

04024-900 São Paulo - SP

Tel: (11)557604118 FAX: (11) 55716579

sandra.dcir@epm.br

keirasmps@uol.com.br 